\title{
Research of undrained shear strength of till fine soils (moraine)
}

\author{
Domas Gribulis ${ }^{1}$, Gintaras Žaržojus ${ }^{2}$, Saulius Gadeikis ${ }^{3}$, Sonata Gadeikyté ${ }^{4}$, Donatas Urbaitis ${ }^{5}$ \\ 1, 2, 3, 4 Department of Hydrogeology and Engineering Geology, Faculty of Chemistry and Geosciences, \\ Vilnius University, Vilnius, Lithuania \\ ${ }^{5}$ JSC “Geotestus" Lvovo str. 9, Vilnius, Lithuania \\ E-mail: ${ }^{2}$ gintaras.zarzojus@gf.vu.lt (corresponding author)
}

\begin{abstract}
The undrained soil strength is specific to fine soils or to sands with a lot of fines. It is very important characteristic and the evaluation of accurate value is significant step. The undrained soil shear strength can be estimated directly in laboratory and indirectly in field using in-situ methods. The values of undrained shear strength estimated with different methods usually are different, sometimes very much. In geotechnical practice a lot of empirical equations are used to calculate undrained shear strength $\left(c_{u}\right)$, however it corrects only in specific conditions and can't be used universally. The empirical factor $\left(N_{k}\right)$, which is used in mentioned equations, varies in wide range. It depends on many factors. The research of glacial genesis fine soils (various moraines) is complicated because it specific grain size distributions and genesis. In this article we will study relation between different laboratory and field methods to estimate of undrained shear strength $\left(c_{u}\right)$ of till soils. For these purposes we will used upper Pleistocene, upper Nemunas formation till fine soils.
\end{abstract}

Keywords: undrained, shear strength, cone penetration, triaxial test, uniaxial test.

\section{Introduction}

The construction rate triggers quick load on soil. Under this conditions the fine soil can ' $t$ quick consolidate, water in voids can 't fast drained out, and the strength of the soil occurs in the undrained conditions. Also these conditions are typical of landslides on slopes or excavations.

The undrained shear strength $\left(c_{u}\right)$ can be estimated from laboratory and field in-situ tests. The procedures of these mentioned tests are often very different, so the obtained values of the undrained shear strength are different to (Mayne, Coop, Springman, Huang, \& Zornberg, 2009). It is important to clearly define which undrained shear the given data refers to. There are numerous methods available to estimate undrained shear strength of clays including till deposits, but there is no information about their reliability in case of Pleistocene glacial deposits. The most common laboratory and field tests methods are: triaxial compression test, unconfined compression test, falling cone test, vane shear test, pocket penetrometer, cone penetration test and others.

Data of till deposit samples of upper Pleistocene, upper Nemunas glacial are summarized and evaluated in this paper. Investigations was performed in two stages: filed in-situ tests and laboratory. During field investigation stage the boreholes were bored, and soil samples were taken. The number of laboratory tests were done in order to describe soil parameters such as: grain size distribution, bulk density, consistency (Atterberg limits).

This paper focuses on the comparison of the undrained shear strength values obtained from direct and indirect laboratory methods of soil analysis and the calculated values out of CPT data using empirical equations.

\section{Research methodology}

Most common direct methods to determination of undrained shear strength are two: uniaxial unconfined compression test and unconsolidated undrained triaxial test. These two tests methods were used to determine undrained shear strength of till deposits. Additionally, as indirect methods, hand vane and pocked penetrometer tests were done.

The main task of a uniaxial unconfined compression test is determination of unconfined compression strength $\left(q_{u}\right)$. The half value of qu is equal to value of undrained shear strength $\left(c_{u}\right)$. During this test the application of deviatoric stress on undisturbed soil sample was quick. The load was increased (compression of sample) up to sample disturbed

(C) 2019 Authors. Published by VGTU Press. This is an open-access article distributed under the terms of the Creative Commons Attribution (http://creativecommons.org/licenses/by/4.0/) License, which permits unrestricted use, distribution, and reproduction in any medium, provided the original author and source are credited. 
or the value of deviatoric stress for some time remains more or less constant (at least 4 data recording times) and value of strain exceed more than $15 \%$.

Theoretically values of undrained shear strength $\left(c_{u}\right)$ obtained by using the unconfined compression test and the unconsolidated undrained triaxial shear test (UU test) should not be differ as both are based on the $\varphi=0$ method. However, this is not the case. The values of cu determined by the unconfined compression test are slightly lower than those determined by the triaxial shear test (UU test).

Calculation of undrained shear strength from CPT was performed using only cone resistance values (cone tip $q_{c}$ ). This is most common and most fast way to calculate $c_{u}$. Classic empirical equation which is based on Terzaghi's bearing capacity theory (Terzaghi, 1943) was used in research calculations (1):

$$
c_{u}=\frac{q_{c}-\sigma_{v}}{N_{k}}
$$

where: $c_{u}$ - undrained shear strength, $\mathrm{kPa} ; \sigma_{v}$ - total overburden stress, $\mathrm{kPa} ; N_{k}$ - empirical cone factor.

But if investigations are provided in depth there the geostatic pressure have not significant value (up to deep to $10 \mathrm{~m}$, where the $\sigma_{v}-$ can exceed about $200 \mathrm{kPa}$ ) we can reduce the classic Eq. (1) to Eq. (2):

$$
c_{u}=\frac{q_{c}}{N_{k}} .
$$

Many analyses have been conducted to obtain typical cone factor values for different soil types. According many authors research the values of $N_{k}$ factor varies over a wide range (from 7 to 25 and more) (Aas, Lacasses, Lunne, \& Hoeg, 1986; La Rochelle, Zebdi, Leroueil, Tevenas, \& Virely, 1988; Rad \& Lunne, 1988). The wide range of cone factor values implies that care must be taken in analysis of $c_{u}$ when using such empirical correlation. They can be used only if there are comparative experiences on similar deposits and geological conditions. The values of $N_{k}$ very depends on grain size distribution, consistency, plasticity and over consolidation ratio (Lunne \& Klevan, 1981; Chen, 2001; Bowles, 1995; Urbaitis, Lekstutytè, \& Gribulis, 2016).

\section{Soil description}

The grain size distribution, consistency, bulk density and moisture content of till soil was determined in laboratory in accordance with standard test procedures described in ISO standards. According ISO 14688-2:2004 investigated soil is low plasticity sandy silty clay with some admixture of gravel (sasiCl). Analysis of grain size distribution show that most varied is fraction of sand (grain size $0.063-2.0 \mathrm{~mm}$ ). This fraction varies from $26 \%$ to $58 \%$ with mean value $37 \%$. The fraction of gravel (grain size $>2.0 \mathrm{~mm}$ ) in all samples is almost constant with the range $1.5 \%$ to $3.0 \%$, in rare cases it has more than $3 \%$ of gravel (Table 1 ).

Table 1. Summary of geotechnical properties of investigated till soil

\begin{tabular}{|c|c|c|c|c|c|c|c|c|c|}
\hline \multirow{2}{*}{ Values } & Moisture content & Bulk density & Void ratio & Liquid limit & Plastic limit & $\begin{array}{c}\text { Plasticity } \\
\text { index }\end{array}$ & $\begin{array}{c}\text { Cone resistance } \\
\text { from CPT test }\end{array}$ & $\begin{array}{c}\text { Undrained } \\
\text { shear strength }\end{array}$ \\
\cline { 2 - 9 } & $w,-$ & $\rho, \mathrm{Mg} / \mathrm{m}^{3}$ & $e,-$ & $w_{L},-$ & $w P,-$ & $I_{P},-$ & \multicolumn{2}{|c|}{$q_{c}, \mathrm{MPa}$} & $c_{u}, \mathrm{kPa}$ \\
\hline \multicolumn{7}{|c|}{ Zone I } \\
\hline Max & 0.166 & 2.28 & 0.455 & 0.353 & 0.189 & 0.180 & 3.9 & 162 \\
\hline Min & 0.095 & 2.18 & 0.310 & 0.200 & 0.101 & 0.059 & 1.5 & 77 \\
\hline Average & 0.130 & 2.23 & 0.378 & 0.260 & 0.133 & 0.127 & 2.6 & 127 \\
\hline \multicolumn{7}{|c|}{ Zone II } \\
\hline Max & 0.113 & 2.34 & 0.34 & 0.281 & 0.130 & 0.151 & 18.6 & 910 \\
\hline Min & 0.063 & 2.23 & 0.23 & 0.179 & 0.108 & 0.068 & 4.0 & 83 \\
\hline Average & 0.092 & 2.27 & 0.3 & 0.206 & 0.116 & 0.090 & 7.9 & 250 \\
\hline
\end{tabular}

\section{Discussion of results}

Our research shown a close relation between undrained shear strength taken from uniaxial unconfined compression test and triaxial UU test results (see Figure 1). The average of differences is $10-15 \%$.

The comparison an undrained shear strength results taken from additional indirect laboratory tests methods (pocket penetrometer test and hand vane) with uniaxial compression test results shown some differences. The values of undrained shear strength taken from additional tests were lower than taken from uniaxial test. The difference is about 30\% (see Figure 2 and 3). Despite the differences of values, the correlation between methods is sufficient strong, where coefficient of correlation $(\mathrm{R})$ respectively is 0.83 and 0.94 . But need to note, that due to admixture of gravel, 
disturbances of sample surface and limit of strength, these two additional methods not always suitable for till deposits to determine undrained shear strength. However, these two methods can be perfect complement to other research methods and can be helpful to soil classification. During preliminary engineering geological investigation mentioned additional indirect methods can help separate the geological strata in to detail layers.

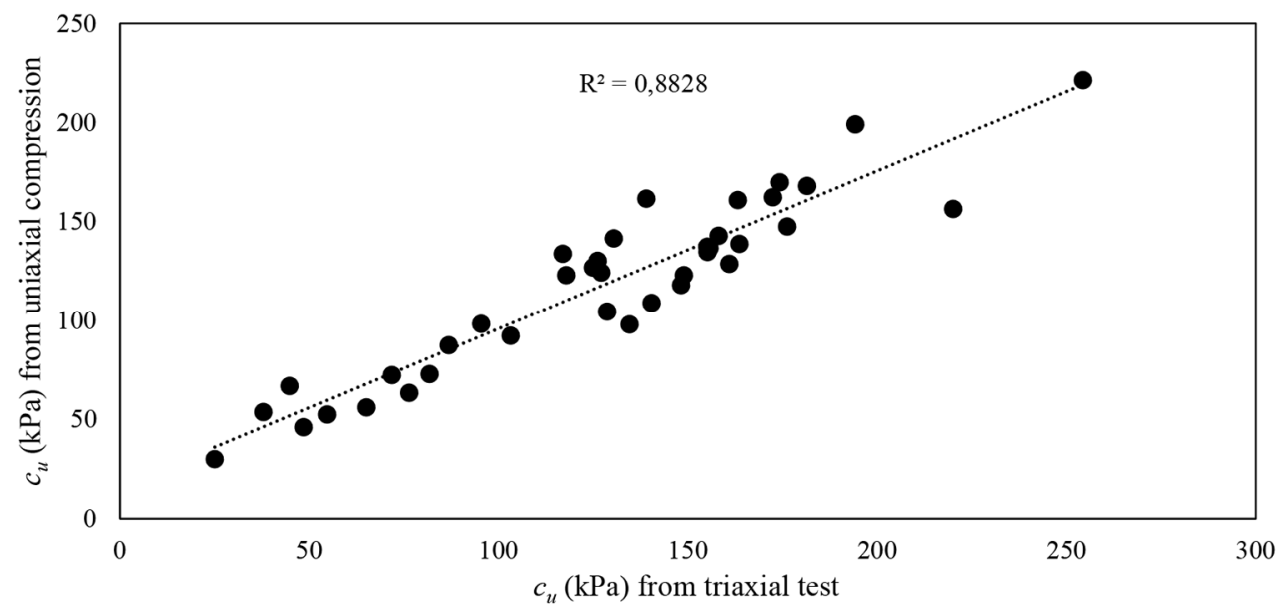

Figure 1. Undrained shear strength taken from uniaxial unconfined compression test vs. triaxial UU test results

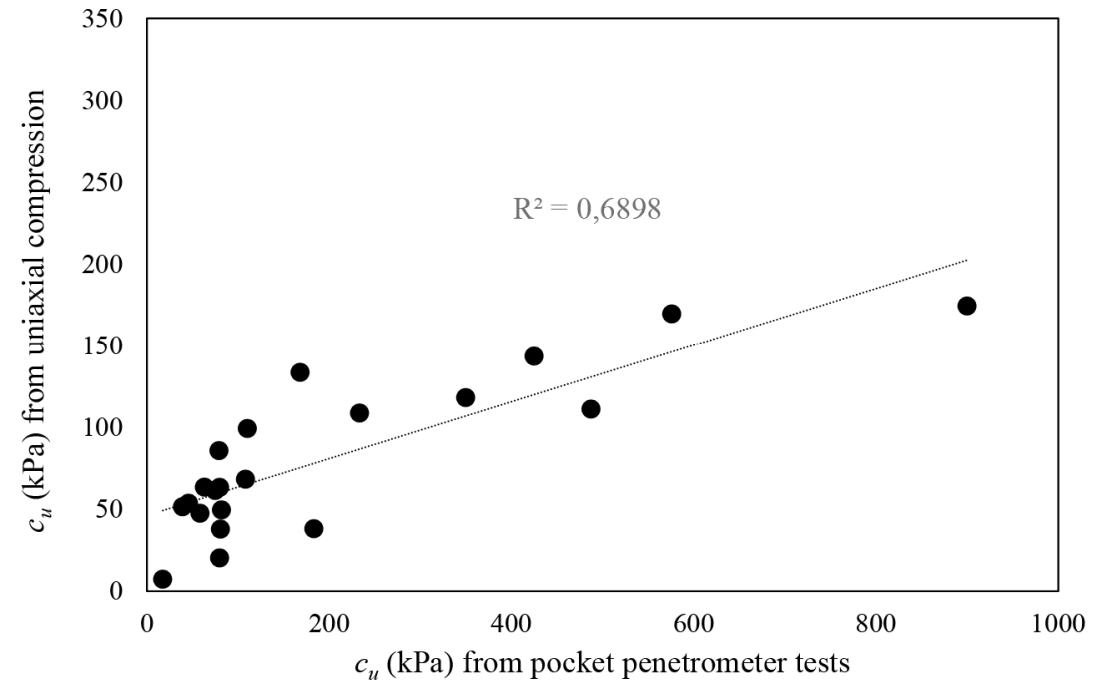

Figure 2. Undrained shear strength taken from uniaxial unconfined compression test vs. pocket penetrometer tests results

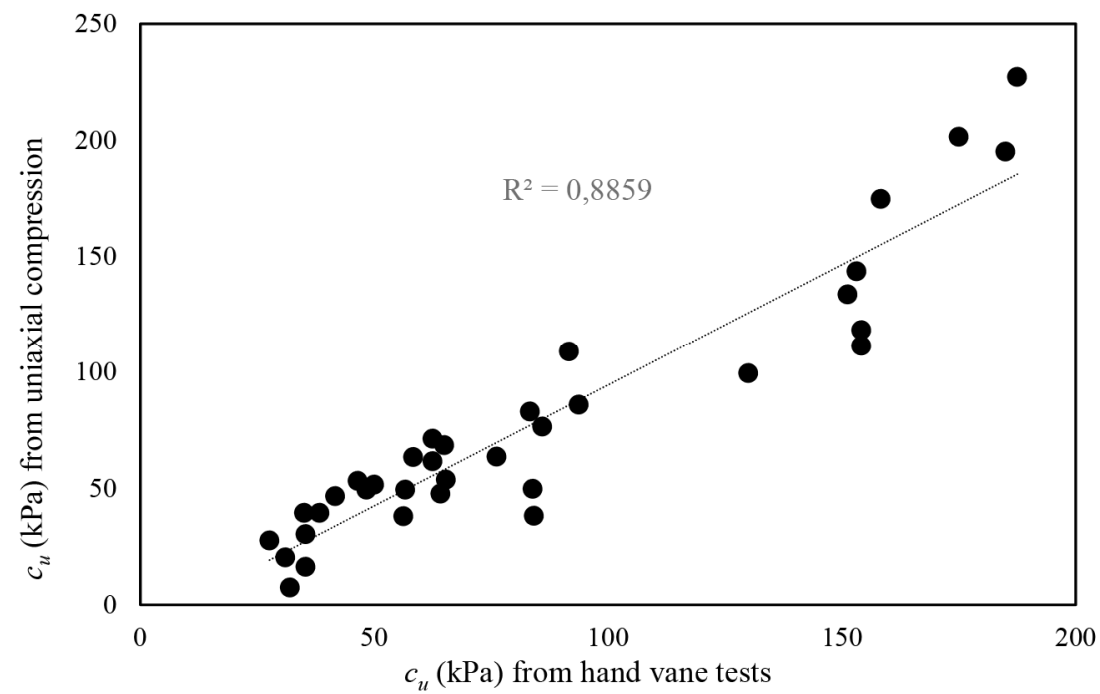

Figure 3. Undrained shear strength taken from uniaxial unconfined compression test vs. hand vane tests results 
This research show, that there is a slight difference between undrained shear strength determined from uniaxial compression and triaxial tests. Therefore, to correlation of undrained shear strength with CPT data was decided to choose the method which is faster, cheaper, less-time consuming - uniaxial unconfined compression test.

The data analysis show, that according $q_{c}$ values all data in correlation chart divides in to two zones (see Figure 4). The limit is $q_{c}=4 \mathrm{MPa}$.

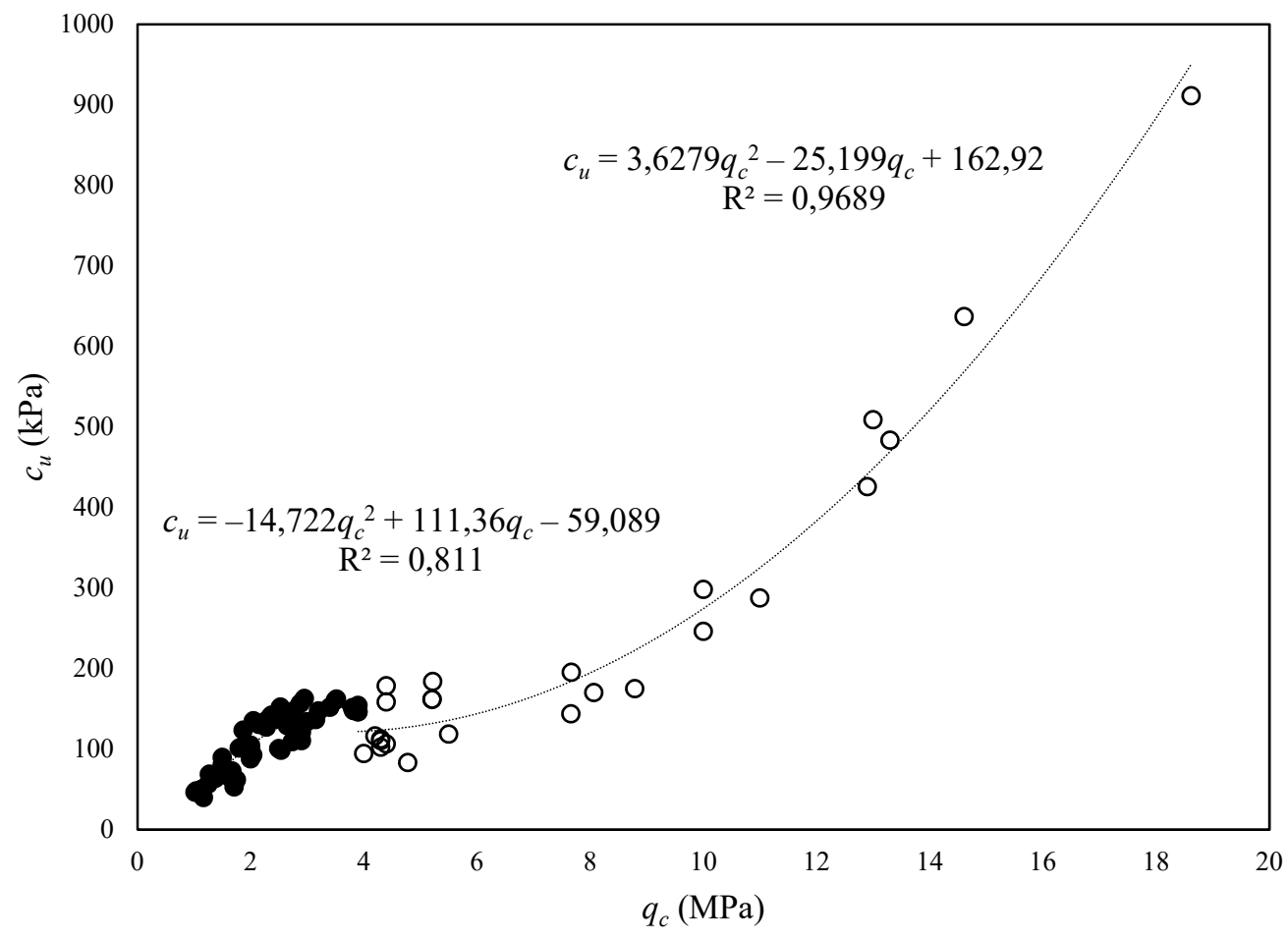

Figure 4. Undrained shear strength vs. cone resistance from CPT. Separation of two zones

The deformations of these two zones is different. According to tests results the first zone soil deforms plastic, whereas the second zone soil deforms - brittle (see Figure 5).

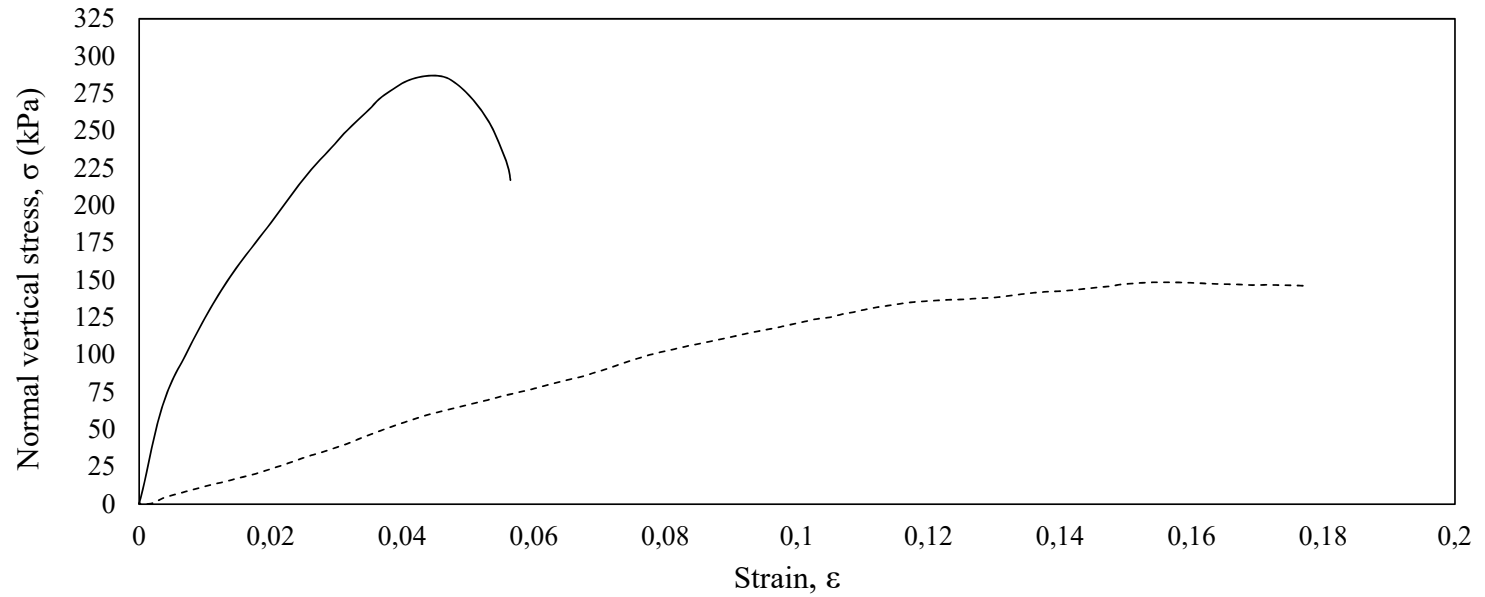

Figure 5. Vertical stress vs. strain: whole curve - brittle deformations (zone II), dotted curve - plastic deformations (zone I)

The first zone $\left(q_{c}<4 \mathrm{MPa}\right)$ soil according grain size distribution is near to the optimal soil composite, which has a lowest compressibility and highest strength. The second zone with the cone resistance values above 4 MPa consist of soil with noticeable increase in sand fraction (see Figure 6), value of moisture content is relatively low, bulk density value is high and void ratio is relatively low (see Table 1). 


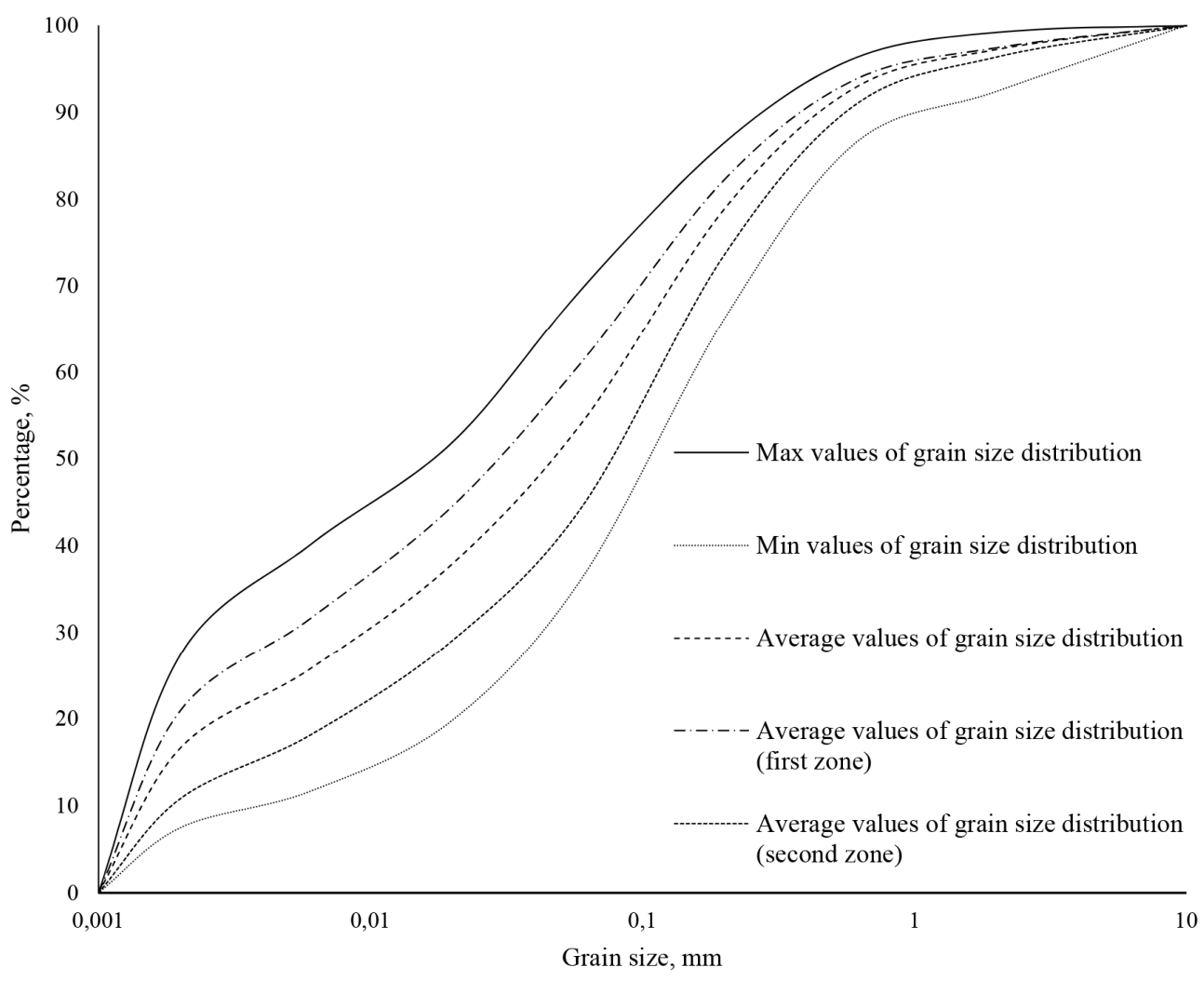

Figure 6. Grain size distribution of tested soil

The results show, that calculation of undrained shear strength from cone resistance is not appropriate to use one value of $N_{k}$ factor. According to local experience cone factor $\left(N_{k}\right) 20$ is used to calculate undrained shear strength from CPT data. The soil separation in to two zones gives a better correlation (see Figures 7, 8 and Figures 9, 10). The coefficient of correlation $(R)$ of the first zone soil increase from 0.86 than $N_{k}=20$ to 0.88 than we use regression (3):

$$
c_{u}=-15 q_{c}^{2}+111 q_{c}-59 .
$$

The second zone $R$ increase from $0.94\left(N_{k}=20\right)$ to 0.98 with linear regression (4):

$$
c_{u}=4 q_{c}^{2}-25 q_{c}+163 .
$$

Hereby, the separate calculation gives a better values of undrained shear strength.

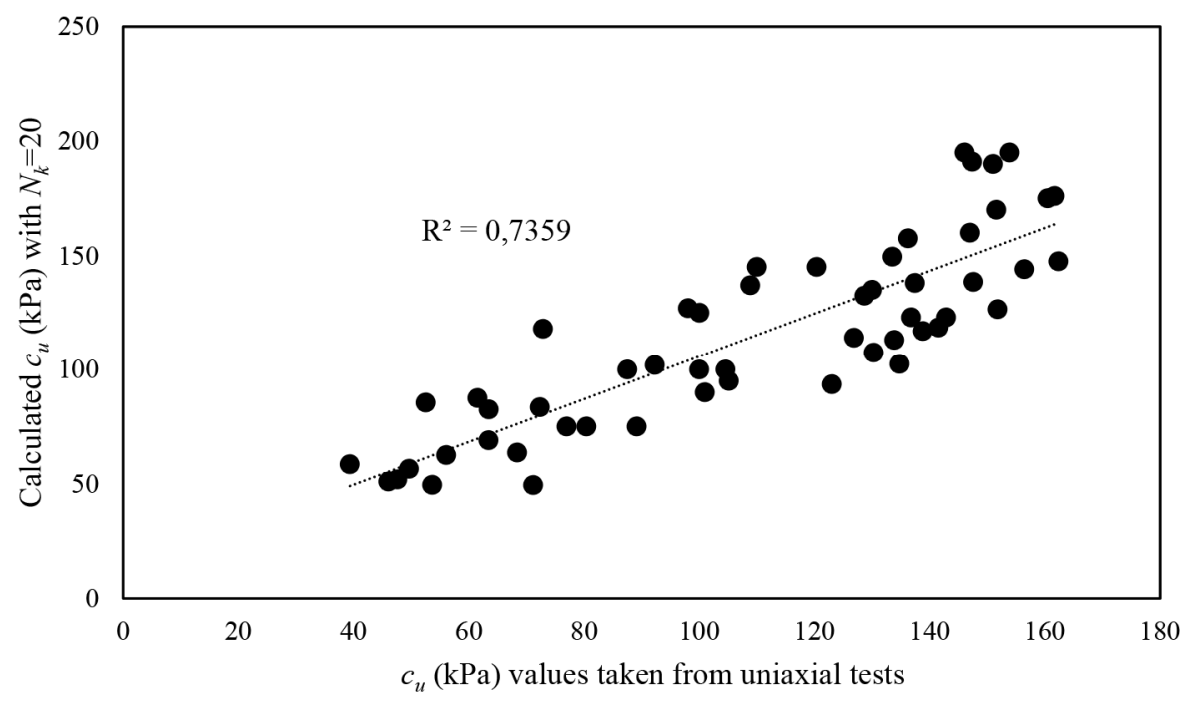

Figure 7. Undrained shear strength values with $N_{k}=20$ vs. $c_{u}$ values taken from uniaxial unconfined compression test (soil zone I) 


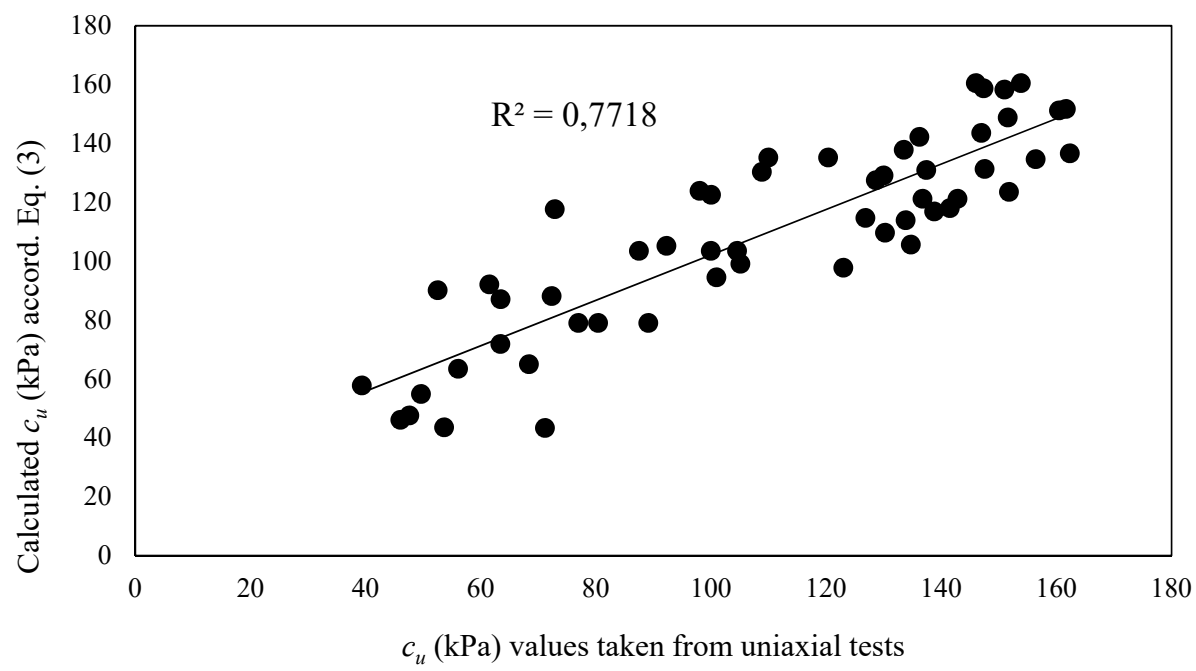

Figure 8. Undrained shear strength values according Eq. (3) vs. $c_{u}$ values taken from uniaxial unconfined compression test (soil zone I)

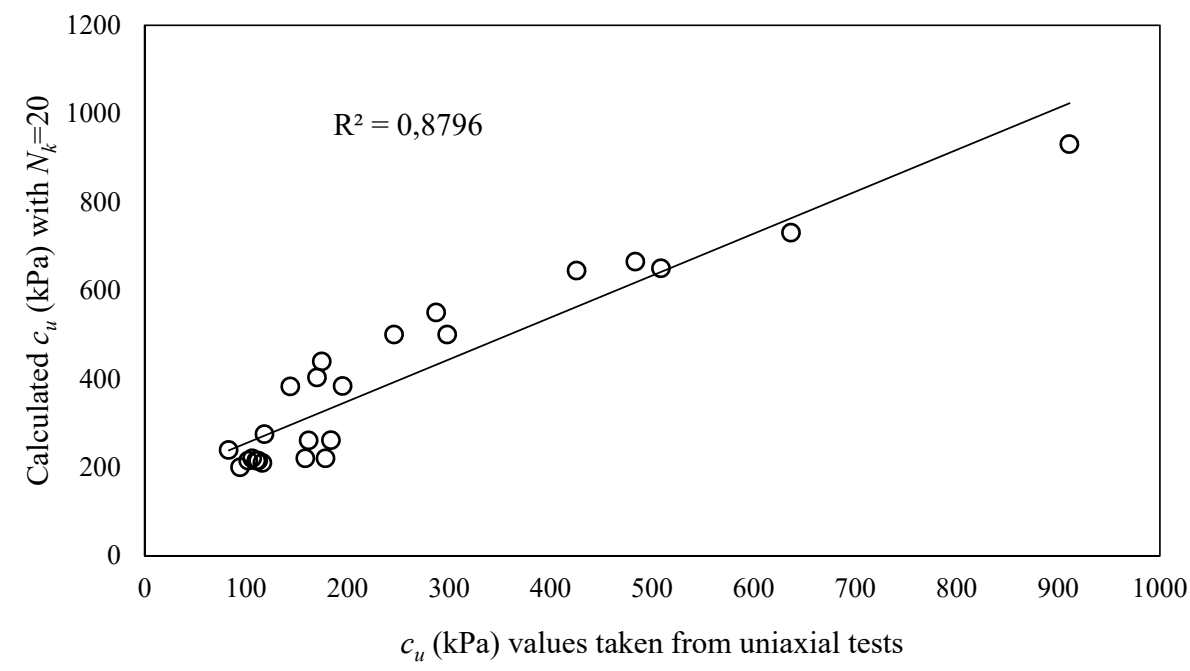

Figure 9. Undrained shear strength values with $N_{k}=20$ vs. $c_{u}$ values taken from uniaxial unconfined compression test (soil zone II)

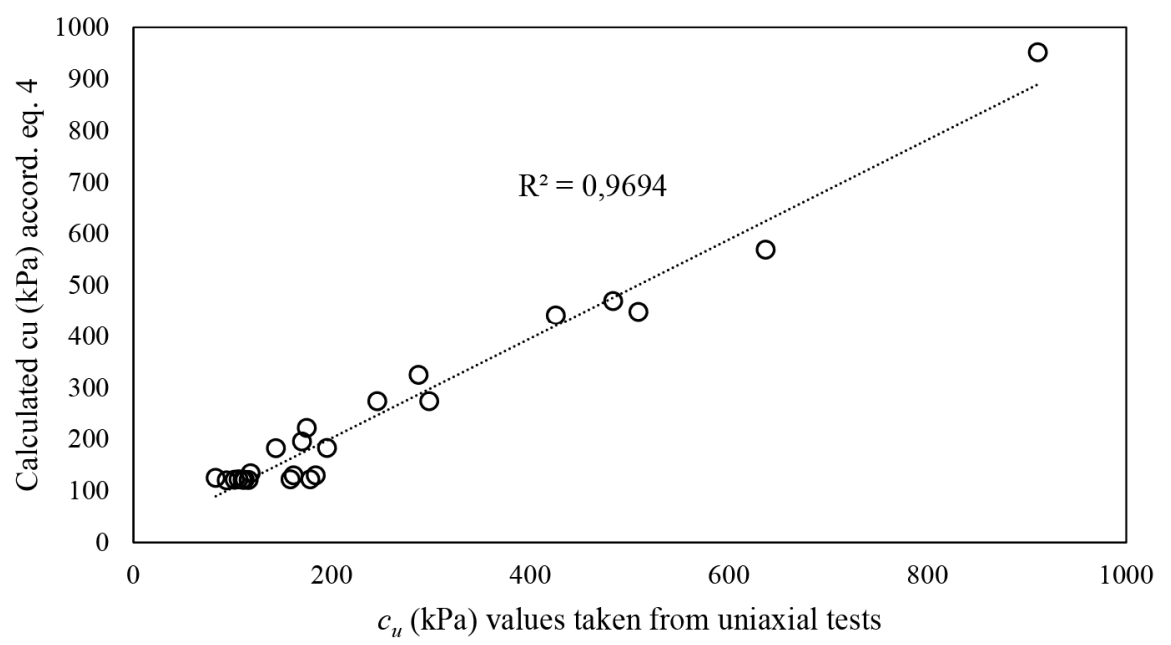

Figure 10. Undrained shear strength values according eq. 4 vs. $c_{u}$ values taken from uniaxial unconfined compression test (soil zone II) 


\section{Conclusions}

Comparing the results of direct undrained soil strength testing methods, it was found that there was a small difference (up to $15 \%$ ) between the obtained values. Therefore, both methods are useful for determining the strength of till sediments in our region.

Based on the results of the study, the values of the undrained shear strength of the till soils determined using indirect methods, can be used to dividing geological section into engineering geological layers (elements) during preliminary engineering geological investigations.

When looking for the correlation between cone resistance $\left(q_{c}\right)$ and the value of undrained shear strength, it was observed that there are two zones at the limit when the cone resistance reaches about $4 \mathrm{MPa}$. Zone I is more clayey till soil compared to Zone II.

According to the research results, we can conclude that it is not appropriate to use a single $N_{k}$ factor to determine the value of the undrained shear strength based on cone resistance values. More accurate results can be obtained using quadratic Eqs. $(3,4)$.

\section{References}

Aas, G., Lacasses, S., Lunne, T., \& Hoeg, K. (1986). Use of in situ test for foundation design on clay. Poceedings of IN-SITU'86 (pp. 1-30). Blacksburg.

Bowles, J. E. (1995). Foundation analysis and design ( $5^{\text {th }}$ ed.). McGraw-Hill Science, Engineering, Math.

Chen, C. (2001). Evaluating undrained shear strength of Klang Clay from Cone Penetration test. Proceedings of the International Conference on in Situ Measurement of Soil Properties and Case Histories (pp. 141-148). Graduate Program. Parahyangan Catholic University.

La Rochelle, P., Zebdi, P., Leroueil, S., Tevenas, F., \& Virely, D. (1988). Piezocone tests in sensitive clays in eastern Canada. Proceedings of the International Symposium on Penetration Testing (pp. 831-841). Balkema Pub. Rotterdam.

Lunne, T., \& Kleven, A. (1981). Role of CPT in North Sea foundation engineering. Symposium on Cone Penetration Engineering Division (pp. 49-75). ASCE.

Mayne, P., Coop, M., Springman, S., Huang, A., \& Zornberg, J. (2009). Goamaterial behavior and testing. Proceedings of the $17^{\text {th }}$ International Conference on Soil Mechanics and Geotechnical Engineering (pp. 2777-2872). IOS Press, Millpress Science.

Rad, N. S., \& Lunne, T. (1988). Direct correlations between piezocone test results and undrained shear strength of clay. Proceedings $1^{\text {st }}$ International Symposium Penetration Testing (pp. 911-917). Orlando.

Terzaghi, K. (1943). Theoretical soil mechanics. John Wiley and Sons. https://doi.org/10.1002/9780470172766

Urbaitis, D., Lekstutyte, I., \& Gribulis, D. (2016). Overconsolidation ratio determination of cohesive soil. Proceedings of $13^{\text {th }}$ Baltic Sea Region Geotechnical Conference - Historical Experience and Challenges of geotechnical problems in Baltic Sea Region (pp. 108-113). Vilnius. Lithuania. https://doi.org/10.3846/13bsgc.2016.014 